\title{
Environmental Education of the Younger Generation
}

\author{
Khusainov Z. A. ${ }^{1}$, Biktimirov N. M. ${ }^{1} \&$ Shigapova N. V. ${ }^{1}$ \\ ${ }^{1}$ Kazan Federal University, Institute of Management, Economics and Finance, Kazan, 420008, Russia \\ Correspondence: Khusainov Z. A., Kazan Federal University, Institute of Management, Economics and Finance, \\ Kazan, 420008, Russia. E-mail: zaudet@in box.ru
}

\author{
Received: March 10, 2015 Accepted: March 31, 2015 Online Published: April 30, 2015 \\ doi:10.5539/ass.v11n11p221 URL: http://dx.doi.org/10.5539/ass.v11n11p221
}

\begin{abstract}
As socially-historic experience shows, non-acquaintance with the culture of your own nationality, its past and present means breaking up of ties with generations, that cripples in formation of pupils' ecological culture and creation of ecological space. Tatar peoples' family life, the way they bring up their children differ from others and it is affected by traditions, customs, holidays and everyday life of these people. The child is growing up and developing in a native verbal environment, traditions of his nation. Traditions, customs, pedagogical and ecological experience of people are in every field of life - economic, political, moral, common, pedagogical and ecological culture. They are peculiar to every culturally geographical regions and tribes.
\end{abstract}

Keywords: environmental, education, ecology, folk pedagogies, generation

\section{Introduction}

A human being was closely connected with the outside world in all periods of its development. Being a part of the nature, he is not able to exist out of the nature, that's why he should keep up with its laws. But occurring of industrial society is the sequence of humanity's bad influence on the nature. Nowadays the intensification of anthropogenic influence on the nature has reached such great levels which lead to global environmental disruptions. It heavily deteriorates environmental condition, endangered by this planet-life combination existence. If humans are going to ignore the laws of nature development, our society is threatened with destruction. So that today the formation of new ideology on the relationships of human and nature is of particular significance.

Under the current conditions environmental education should be carried out from the early childhood and be a continuous and stable process, the aim of which is ecological culture development of pupils.

In connection with increasing influence of humanity on the nature in $20^{\text {th }}$ century, ecology has taken a particular meaning as scientific basis of environment conservancy. From the 70 -s of $20^{\text {th }}$ century a theory of human ecology or social ecology which studies regularities of society and nature integrity from the perspective of its protection has been developing. It includes different aspects like philosophical, social, economic and geographical aspects.

Psychological direction of the lessons, its structure during education of nature studying subjects, seeing the interrelation between human and nature are allowing to pupils to be self-aware as a part of the nature. They are beginning to understand the meaning of importance of nature education development and their own possibilities in relishing of nature only by finding themselves to be a part of the nature. That is the first step to the ecological culture. As the result pupils get a habit of environmental friendliness and finally they do everything that is necessary for environmental development of their districts, schools, gymnasiums etc.

Generalizing their surveillances over natural phenomena, the Tatar nationality gained experience and practiced it in everyday life: well opened ground, enriched soil with non-hazardous compounds, planted out of season, had a mowing-time, carried corn etc. Experience, traditions and customs of the nation are also reflected in the language: sayings, proverbs, riddles, legends, songs, baits, etc. So they have become the jewels of ecological education, experience and passed on from generation to generation by means of continuance of traditions, customs and holidays. This nationality was basically agricultural from the ancient times; their system was directed into rational usage of ground which kept partially unreduced. Human was reliant absolutely on environmental conditions and that is why his consciousness supposed unity of human with nature. From this point of view human cannot exist without nature. 
Nature phenomena have many mysteries, on which science cannot find any explanations. All its components interrelate in the nature. There are a quite number of cases when people's observation anticipated the things which were proved further by science. From this point of view folk wisdom is extended and extends the perspectives for the next scientific observations and discoveries in ecology. The great history of Tatar nation, early nationhood can be argued of its high ecological culture.

It should be mentioned that in spite of natural habitat every culture has its own traditions, customs; they have the same treatment of conservation.

\section{Methods}

To disclose the content of scientific work, the following methods were used: theoretical, logical, historical, pedagogical and ecological analysis of various aspects of the problem; theoretical generalization of the research results, taking into account key factors and specific conditions; study of environmental information on the topic; analysis and synthesis of educational, ethnographic and ethno-ecological sources, archival materials and documents on the environmental culture of the Tatar people and the ethnic groups living in the region.

\subsection{The Type and Methods of Research}

Based on the principles of natural development, natural education and problem-based learning, we have formulated the following provisions for formation of ecological culture of students, composing conceptual framework.

\subsection{Ecological Aspects in Family Education}

As socially-historic experience shows, non-acquaintance with the culture of your own nationality, its past and present means breaking up of ties with generations, that cripples in formation of pupils' ecological culture and creation of ecological space.

No one else except Kayum Nasyri - one of the Tatar writers, scientists, teachers of the second half of the 19th century didn't stand for importance of the native language in educational process. He put a lot of effort in order the Tatar language to become the language of science and literature. Kayum Nasiry attached the greatest importance to family upbringing, gave some advice to parents to develop their pedagogical culture. "Upbringing is not carried out during the feeding, at the same time it is living with him and caring about his moral perfecting, inoculation of noble manners, intention to make from him a considerable human, knowing the science and decency conception".

Following K. D. Ushinsky, K. Nasiry advanced an idea of national education, highly estimating environmental education traditions of Tatars. At that time the word "ecology" wasn't used, but such a notion was in the scientist's doctrinal content. Communication with people, gaining inside into spiritual world and culture of his people helped him to write and publish valuable information on environmental education and he widely used them in his pedagogical activity. His works "Education book", "Forty gardens", "Morality book" have great information about Tatar folk pedagogy and ecology.

Every nationality has its own system of education, which includes different methods of children training to future; they have their own pedagogy, passing from generation to generation. Ethno pedagogy, being the result of public creative idea of many generations and expression of interests of popular majority, in accordance with its requirements to environmental safety, puts forward ecological standards in the sphere of young generation upbringing.

Taking into account the loss of the traditional pedagogy of the Tatar people, there is a great omission in modern conception of children education. In ancient times people brought up their children according to their own system. Consisting of two or three generations family gave a child wise, implanted morally ecological culture, respect for environment and people. There were nature oriented and common interdictions in people's tradition of those times. For example there was a wide range of ecological bans to living world, nature.

Tatar people were shooting for one or another animal at a given time, at the same time they didn't make any harm; for instance, "weeks of quarter" were conducted in breeding period, it was forbidden to touch the eggs in nests. Parents explained it with the following facts: birds can send diseases and different fiends, which kept children from bad behavior. Khusainov Z. A. writes: The aim of the study is to develop the content and methods of forming of ecological culture of the students of the national school-based knowledge of the Tatar people on the nature (Khusainov, 2012, p. 208).

Especially it referred to birds, living nearby with human (pigeon, starling, sparrow etc). Under the special protection were beneficial insects: ants, bees, spiders, and others. There was even the so called "taboo" towards 
to them - not to kill. It is said for example: "if you destroy the ant hill, your hands will wither", "if you kill a spider, your legs will wither" etc.

People had their own proverbs and spells for every case, the outcome of which was impressive.

Consequently, careful treatment to the nature was reflected in the educational system. Interdictions and literary instructions were essential ways of education, which kept children out from aimless elimination of birds, animals and plants.

The system of education, changing from child development is called "sin". It is based on compassion, forgiveness, good nature. Responsibility of children before the God was defined by their behavior.

Education system "sin" was the background standard of human behavior. Violations, making an exhibition of society were considered as a sin before the God. This system is connected with nature and social life. It has appeared in nature and became a way of life of every family. Common laws of morality, environmental friendliness were based on it.

Opinion polls taken by teachers-investigators among parents and pupils helped to determine the role of family upbringing in the development of ecological culture of pupils on the base of Tatar people ecological knowledge.

Home flower cultivation was widely held in everyday life of Tatar people. Many songs are about the love to flowers, praising their beauty.

Learning everyday life of family and peculiarities of Tatars' folk traditions, K. Fuks wrote: "Basil (Ocymum basilikum) is the favorite flower of Tatars, they like the way it smells. Here Tatars set out their windowsills with basils, nasturtiums, balsamine and very rarely with other kinds of flowers" (Fuks, 1844, p. 112).

Having no life experience, children try to copy their parents' behavior and actions. They explain it as follows: "My father plants trees like this", "My mother taught me to pill potatoes like this". In this regards V. A. Suhomlinskiy wrote: "Family keeps good folk traditions" (Suhomlinskiy, 1981, p. 35). Tatar folk pedagogy used the example of mother, her image as the effective one in children upbringing. Image of mother, her kindness and fidelity to children is praised in folk art. Creating of Mother's cult doesn't only mean to accept her educative role, it means that no one honest man can be brought up without love and respect to mother. As G. N. Volkov put it: "If the ancestors are about the past, field of beliefs, children are about the future, so mother is about the present, and her activity is directed into upbringing of youth generation" (Volkov, 1970, p. 304).

Tatar peoples' family life, the way they bring up their children differ from others and it is affected by traditions, customs, holidays and everyday life of these people. A child is growing up and developing in a native verbal environment, traditions of his nation. Traditions, customs, pedagogical and ecological experience of people are in every field of life - economic, political, moral, common, pedagogical and ecological culture. They are peculiar to every culturally geographical regions and tribes. Khusainov Z. A. writes: Ecological culture of a personality is being formed in the integration of the three areas: environmental consciousness, moral-aesthetic, active, practical relations (Khusainov, 2012, p. 209).

Komenskiy started his career as a researcher of folk traditions and customs. His pedagogical system was a theoretical justification and development of people's education. Generalizing experience of home nursing, he developed an idea of "Mother's school".

Pestolazzi I. G. based a folk school on native language, using vast experience of Switzerland folk pedagogy.

Ushinskiy K. D. highly respected pedagogical thoughts of people, their great experience in upbringing and education of coming generation. Putting the aim, character and methods of folk education he made his own conclusions that every nation has its own system of education, upbringing. The main idea of Ushinskiy pedagogical theory and system is upbringing of the nationality (Ushinskiy, 1948, pp. 122-225).

Still we can observe elders cult in countryside. And the reason is their own houses, property. From the first days of being in this world a child is feeling every beauty of native shores, landscapes and puts all forces to make it better. That is a good basis for environmental education.

The most pedagogical functions in upbringing of children, teenagers and young people are placed on their parents.

Fellowship between members of a family and also parents' relationship influence on family education. That is why one of the important factors of the Tatar nationality is a united family. Only a good atmosphere in a family can make a difference in environmental education. "Friendly family lives in blessing, but where there is a quarrel, there the perish is". A head of the family - father was responsible for education and upbringing of children in 
Tatar families. However his way of living gave a little chance to face children at home. The most part of time he spent at work. Trying to pay equal attention to all children, still sons were closer. Parents remembered their responsibilities to bring up a good farmer and breeder. During upbringing a father paid a great attention to physical and ecological education of his sons. He familiarized his children with environment during farm labor, grazing of livestock and told about complicated natural phenomena with specific reference.

There are many practices in traditions of education, especially regarding farming and cattle breeding. This knowledge, worked out during centuries-long experience helped to keep the environment in safety. Natural management and environment conservancy fields also included environmental awareness of people about useful plants, palatable grasses and berries and compounding medicines from them. From the very childhood children got environmental knowledge stored by their parents. In practice, for example, they took into account that is forbidden to kill a dam with her calves; captured whitebait should be certainly released etc. Tatar people emphasizing a great part of a father in upbringing said: "In fishing took after father", "What is the father, so is the son" etc. Khusainov Z. A. writes: Ecological culture, intelligence, spirituality and unbridled passion for profit, absence of control and animate egoism two incompatible directions (Khusainov, 2012, p. 220).

According to Tatar people, parents' love is the greatest and irreplaceable source of child's intellectual development, his emotions, morality and confidence. Parents' love is ever-living source of tenderness, understanding, carefulness, love and other gentries. As A. C. Makarenko wrote: "People brought up without parents' love are often spavined people" (Khusainov, 2012, p. 24).

Wise old men - aqsaqals: grandfather and grandmother were respected tutors in Tatar families. Everyone took their advice; they sat at the head of the table, and invited to settle different disputes. Such respect for elders is explained by their great experience and deep knowledge. Wiser ones were respected not only in their families but also in other families among youths. Islamic theory and practice is the basis for creating value system. It makes mentality and reality of many people. Developing ecology and morality are closely connected in Islamic traditions. So Tatar's mentality includes altruistic attitude to all flesh, moderation, healthy way of life, environmental friendliness. Talking about cultural, psychological and pedagogical heritage of Islam, we mean moral, spiritual and humanistic basis which can be used in educational process of ethnic schools.

"It's necessary", "It's forbidden", "It's possible" - understanding of these three moral truths and pursuing them is talking about high morality. But only the person, who practices both simple and wise pedagogy, can be developed morally. Ecological culture begins from things and creatures which surround a child (environment flower, birds, trees etc).

Praying (which is one of Islam religion obligatory guides on the basis of Koran) means invocation or sainting words. Prayers should think about their ecological cleanness. Sharp evidence of above-mentioned is the example from Koran: “...If you are going to pray you should do ablution" (Al-Muntahab fi Tasfir al-Kuran al Karim, 2001, p. 98).

Ablution has two meanings. The first is to turn to the God with fervent in the eyes, to stand before Him with open, devoted soul and heavenly thoughts. The second is the cleanness of the body. Ablution cleans the body from pathogenic germs, intensifies blood circulation, tones up, and helps to relax. Accuracy and cleanness are the main factors in prayer's clothe. It should be also added that praying is also gymnastics and hygiene at the same time. Praying ceremonies help to keep a body in a good condition and also develop person's spirituality. So Islamism is promoted to keep moral climate of the society. Everything, what is harmful to the health, is forbidden. Ecological and moral values founded in Koran are promoted in developing following characters: respect to seniors, ambitions, apple-pie order, tidiness, etc. Environmental principles can be found in many pages of Koran. The basis of many ethic norms, moral and ecological personal qualities is honoring mother and nature. Environmental friendliness is reflected in Koran: "We ask you to keep in safe everything we gave you and be kind." (Al-Muntahab fi Tasfir al-Kuran al Karim, 2001, p. 14).

Special attention is paid to one of the important parts of Islamic religion - respect and honor to parents. It is said in Koran: "Allah commands to human to be polite and kind to his parents" (Fuks, 1844, p. 369). "Your Lord told you to worship only Him, love and honor your parents. If one of them gets sick or they both reach a great age, do not swear them, be polite and tell only soft words which show your love and honor. Be kind, gentle and tender-hearted to them and say: "Our Lord, please, forgive them as they forgave and brought me up when I was a child." (Al-Muntahab fi Tasfir al-Kuran al Karim, 2001, p. 262). Koran invocates many times Moslems to be beneficent to their parents: "We command a human to be beneficent and kind to his parents" (Al-Muntahab fi Tasfir al-Kuran al Karim, 2001, p. 472). Consequently surah invocates to be kind and face up to the parents' responsibilities. 
In his researches K. Fuks stressed the role of education and religion in a family. “...If Tatar is not able to read or write, he is despised by his landsmen and has no respect. That is why any father tries to send his children to school as soon as it's possible, where they could learn to read, write and get some knowledge about their religion" (Fuks, 1844, p. 114). He emphasizes the role of religion in getting the education among women: "...Almost all Tatar women living in Kazan get education, and there are few of them who can't read or write. Mullah's wife teaches them here in a new mosque: she has a great faculty for these subjects". (Fuks, 1844, p. 119).

Islamism is based on mercy in the sphere of social questions. According to Koran, moral responsibility of any Muslim includes not only the parents. He is also responsible before his neighborhoods and relatives. We cannot get round the question of morality and religion relation because during the centuries religious moral had educational role in the society.

According to Islam religion, only due to sense human is responsible before Allah and society. Sense is the greatest gift to human.

The results and discussion of the results of the study were provided by:

1. Systematic approach to the research problem, the adequacy of the methods of its goals and objectives;

2. The combination of the generalization of practice and experimental work, the research on the basis of the gymnasium № 4 of Kirovsky district, Kazan, in the scientific-experimental laboratory "New pedagogical technologies in teaching regional geography and ecology" at the chair of economical geography and methodology of teaching geography of Tatar State Humanitarian-Pedagogical University;

3. Scientific testing of the most important ideas, hypotheses and conclusions in schools № 23, 81, 139, in gymnasiums No. 4, 18, 155 Kazan; in Drozhzhanovsky District of the Republic of Tatarstan - in Malotsilninskay, Bolshetsilninskay, Staroshaymurzinskay schools (with teaching in Tatar language); in Starodrozhzhanovskay (with teaching in Russian language), in the Old-Ubeevskay, New Ubeevskay schools (with teaching in Chuvash language).

\section{Discussion}

Key factors of ecological culture are mercy, kindness and tenderness. So, children in A. Ibragimov's family were brought up by their grandmother and grandfather in the village Small Cilna of Drozhanoy district in the Republic of Tatarstan. Grandfather Agsam and grandmother Gulsina have a great respect in this family. Everything what they say to children goes. And this is not under duress. Children were brought up according to moral values of ancient Tatars and unwritten canons of nature. From the childhood grandfather and grandmother talked to grandsons about their nation experience and thereon they learnt to be kind and take care of nature.

If everyone in a family respects each other, it creates favorable conditions. The elders are interested in education and behavior of kids, and try to introduce them to nature. They draw their attention to quality of performed work, to their attitude towards the nature and good housekeeping. Looking after his grandsons, grandfather M. Vahitov always claimed: "You should keep order at home on your own" or "Cleanness is a source of health".

People found parents or the older generation's example as one of important ways of upbringing. They had a weighty part in good environmentally-moral education. Teachers-experimentalists (A. Sadeev, A. Serdcev, R. Husainov, R. Alimova, A. Mistyakova, N. Fazilov etc.) brought to light that human is the son of the nature and the nature is the human's home in their lectures and dialogues.

Tatar people understood it and had an intimate relationship to nature. The same was the upbringing of young generation.

All these problems were especially discussed in lectures. It was noted that a human, growing with love to nature, derives the strength and inspiration from it. That is why motherland is so important to human. Every child of the modern generation should know this fact.

One of the ancient and greatest traditions of Tatar people is the so called "galleys". Every pupil of schools and gymnasiums of Kazan Kirovsky city part could take part in such arrangements. Pupil's family members took active part in this arrangement, they got into the nature with their children, collected garbage, found the equipment for its disposition and together with teachers organized and controlled work of children. Moreover, parents together with their children planted trees and bushes. As a result there were planted for a 1200 meters length trees.

So effective and positive outdoor work has some results: children began to value and take good care of it. Experimentalist teachers have convinced that using of pedagogical and environmental knowledge of people helps to bring up children with environmental friendliness. 
As a result, a family, based on marriage and consanguinity, makes the people united. Every Tatar family had its own system of upbringing, which was based on mother's and grandmother's love to child, obeying of father, that kept the child away from different troubles. Practicing Islam religion parents taught their children to be disciplined, responsible to parents, neighbors, relatives; and in the future this responsibility would be reflected in naturally-social environment. Every family has its own national method of upbringing; behavior common laws directed on environmental conservancy were created on this base. Passed from elder generation to youth, pedagogical and ecological knowledge laid out sound foundation on children's consciousness.

Tatar people have their own ways of nature perception and communication, their own way of initiation to environmental friendliness. But there was silence in some stages of society's development. That's why old and good traditions of people should be restored.

Getting to know the nature begins from the early childhood. Children are very active by their nature: they take simple to environment, feel the adults' music rhyme. Lullabies played the special role in children's life. Tatars developed their pedagogical traditions in high antiquity. They were expressed in folk art. Being the important part of national culture, folk art was used in upbringing and development of ecological culture of a person.

As a rule, folk art creations have deep content, connected with life. Tatar folk art is rich for different styles: proverbs and sayings, fairy tales and riddles, epic stories, legends, songs, baits and munadgats etc. Their way of live, economic set-up, household, pedagogical views and ecological culture are reflected in oral folk arts. Circulating from one generation to another Tatar folk art bears the traces of the past historical facts.

\section{Conclusions}

In the current conditions, ethnic and general education schools are set a goal of forming ecological culture of a person. This requires ecologization of the education.

In solution of the most difficult and major ecological problems, subjective factor of a person, which is the level of his understanding, awareness of his responsibility before future generations for the state of the environment, is of no small importance. That is why the subject of environmental education is so important nowadays. And school has a major role in this process.

In the past centuries people had ecological wisdom and felt the nature. Pre-Islamic period is characterized by the nature deification. So Tatar people highly respected and respect native habitats, especially the holly springs. Nowadays Tatars remember it as the existence of different insubstantial powers. Human's attitude towards these unsubstantial powers set some rules to the behavior in the nature, which is based on respect of the environment. Such way of life had a great significance in keeping primevalness of the environment because it protected fauna habitants during the breeding period.

The following subjects which studied nature, its fauna and flora, atmospheric effects and gained a lot of practical knowledge are ethno history, ethno pedagogics, ethno philosophy, and ethno psychology. Many proverbs, sayings, riddles, signs, fairy tales, legends, baits, munadgats, and other types of oral folk art have proved that. Such regional, pedagogical and ecological knowledge is reflected in empirical observations, pedagogical experience, traditions, and customs. Efficiency of any measures, taken for environmental integrity, finally is defined by older and younger generations' attitude towards the nature.

Ancient Tatars' ideology made impact on their social behavior and formed environmental conservancy. It included required limitation of using natural resources. This knowledge and spiritual values were passed from one generation to another in various ways and were based on ethno pedagogy of the nation which helped to form ecological culture of children. Our investigation shows that technocratic thinking model is so strong that overcoming of ecological crisis seems like traditional - adoption of environmental laws, development of environmentally friendly products, monitoring of innovative technologies etc. Ecological crisis seems like something external, rather than internal for a human.

Therefore, nowadays it is necessary to give ecological education from the early childhood, in order to develop ecological culture.

One of the aspects of ecological culture is the ecological ideology. It is the system of generalized views on people's attitude towards the environment, consciousness of the necessity to limit the consumption. But ideology of consumption is prevailing in pupils' mind. This consumption is environmentally destructive because it prevents from saving country's and region's ecological resources. Thus it is great pedagogical challenge to develop ecological culture (environmental friendliness) in children. Our conceptual frameworks show theoretical and practical ways of development ecological culture of the young generation. 


\section{References}

Al-Muntahab fi Tasfir al-Kuran al Karim. (2001). Russian version of Koran (1st ed., p. 639, Translation from Arabic language). Kazan.

Fuks, K. (1844). Work/ Kazan Tatars statistically and ethnographically (p. 131). Kazan.

Khusainov, Z. A. (2012). Ecological Culture schoolchildren (p. 401). Monograph. Deutschland, Saarbrucken, Palmarium academic Publishing.

Makarenko, A. S. (1988). About upbringing/ the author of prolusion Helemendik V. C. (p. 256). Moscow: Polit. Publ.

Suhomlinskiy, V. A. (1981). I give my heart to children (7th ed., p. 382). Kiev: Ryadanska school.

Ushinskiy, K. D. (1948). Works: About nationality in social education (11th ed., pp. 122-225). Moscow: Pedagogical Sciences Academy RSFSR.

Volkov, G. N. (1970). Good practices of the Chuvashes (p. 96). Cheboksary: Chuvashian book Publ.

\section{Copyrights}

Copyright for this article is retained by the author(s), with first publication rights granted to the journal.

This is an open-access article distributed under the terms and conditions of the Creative Commons Attribution license (http://creativecommons.org/licenses/by/3.0/). 